\title{
The Study on the Effect of Casino Tourism Policy : Focused on the Casino Tourists Service in Macau Area
}

\author{
Youngsoo $\mathrm{CHOI}^{1}$, Chansoon $\mathrm{KIM}^{2}$ \\ 1 First Author Professor, Department of Business Administration, SeHan University, Korea \\ E-mail: shinan0803@sehan.ac.kr \\ 2 Corresponding Author Doctoral Candidate, Department of Business Administration, SeHan University, Korea \\ E-mail: wdch2183@hanmail.net
}

Received: 18 May 2020. Revised: 31 May 2020. Accepted: 11 June 2020

\begin{abstract}
Purpose - This study is regarding customer service environment in casino marketing under a study on the factors affecting casino tourist satisfaction based on casino tourists' various needs.

Research design and methodology - The study of casino tourism policy factors is proceeded by interviewing tourists of Macao casino. A total of 220 copies were distributed and 193 copies were collected, but 13 copies were not conceded due to insincere responses, and a total of 180 cases were analyzed for this study. Based on the analysis results, the casino tourism policy factors were derived through satisfaction level of casino tourist service as follows.

Results - Firstly, the casino tourist satisfaction is a positive influence on casino visits, so efforts should be made to enhance tourist satisfaction when establishing cultural experience programs and casino marketing strategies. Casino culture for tourist should be matured to develop casino tour. In order to increase the satisfaction level of revisiting casino resorts, various cultural products such as clean environment should be developed to enhance the satisfaction level of casino visitors in the future. Secondly, a positive impact of cultural, experiential visits and psychological motivations affect to tourists' psychological stability through cultural experiences as well as casino games. Thirdly, casino tourist satisfaction has been shown to provide a positive impact on behavior intention.
\end{abstract}

Conclusions - Based on the results of this research, the marketing of casino tour is to identify tourists' needs and increase satisfaction.

Keywords: Casino tourism, Motivation of casino, Satisfaction, Behavior Intention

JEL Classification Code: M31, Z32, Z33.

(c) Copyright: The Author(s)

This is an Open Access article distributed under the terms of the Creative Commons Attribution Non-Commercial License (http://Creativecommons.org/licenses/by-nc/4.0/) which permits unrestricted noncommercial use, distribution, and reproduction in any medium, provided the original work is properly cited. 


\section{Introduction}

In modern society, the casino industry is developing with a great economic ripple effect. Casino foreign currency imports are flowing into the country or the local economy, which plays a major role in various ways, including the effect of creating production and added value for related industries, income and job creation for local residents. It also positively affects to revitalizing the local economy, attracting tourists and increasing tax revenues (Won et al., 2005). Since 1990, the casino industry has been focusing on becoming a tourism product, moving away from the concept of "gambling" and growing much faster than other industries (Lee, 2007).

Until modern period, the casino industry had difficulties in generating demand for casinos as it focused on table games and guesthouse facilities. In addition, various problems of uncertainty such as continuous interest and revisit ratio were arisen due to the existing casino tourism industry relies only on the facilities and natural environment of tourist sites. Therefore, promotional activities using marketing mix (price, place and promotion) are being strengthened in the modern tourism industry (Yang, 2014). The 21st century casino industry is undergoing innovative changes to attract tourists. The casino industry is developing into a hub of the tourism industry such as comprehensive resorts, entertainment centers, culture centers and shopping centers to arouse tourists' curiosity. Therefore, each country is preparing new marketing to enhance its image and attract casino tourists. In order to attract new casino customers, various slot machines are required to provide and casino customers' needs are studied to revitalize casino tourism. This study provides a theoretical system for attracting tourists and improving competitiveness of casino services in the future by analyzing the satisfaction level of cultural, experiential and psychological motivation of casino tourists visiting Macau.

The purpose of this study is to provide directions for creating a competitive environment for the future casino industry by analyzing motivational factors of tourist satisfaction that can be found as a tourism product due to the characteristics of casino, and to suggest basic conditions in which the service environment of casino operation can be changed from gambling to tourism industry through motivation factors of visitors. Therefore, the spatial background of this study has been established as Macau, which has recently grown into the world's largest casino market. Moreover, the participants were targeted at Koreans and Chinese visiting Macau, and the factors of tourist satisfaction to casino tourists were studied and analyzed.

The research methods on casino policy factors were analyzed based on domestic and oversea advance research and empirical analysis was conducted focusing on the theoretical systemization and case studies of casino tourism. Through this, a research model was designed and a questionnaire was prepared through the setting of the research hypothesis. Current situation and problems of each country's casino industry were studied through academic and professional literature materials. In particular, the domestic survey of this study was difficult to accomplish due to critical awareness of casino customers. Therefore, the survey was organized through an on-site survey of Macau resort, the world's largest casino resort. Therefore, the purpose of this study is as follows; First, establish the relationship between casino selective attributes (game facilities, indoor atmosphere, human service, customer relationship maintenance, casino reputation and safety) and customer satisfaction and follow-up behavior through literature study and empirical study. Second, verify the relationship between customer satisfaction and follow-up behavior. Third, provide the strategic implications and measures to enhance casino marketing performance by verifying that customer satisfaction mediating casino selection attributes and post-action intentions.

\section{Literature Review}

\subsection{Characteristics of Casino}

In the 21 st century, the world's tourism industry has seen a growing number of tourists due to the development of specialized tourism products such as casino tourism and theme tourism. The World Tourism Organization estimates the value of world tourism market will be 3 billion dollars in 2030. Casino tourism is one of the categories of tourism resources and serves as a driving force for the development of the tourism industry. Therefore, casino tourism plays following roles through tourists as a tourism product. First, manage motivation and behavior of tourists. Second, commercialization of tourism by connecting consumption and supply aspects of casino. Third, activities for satisfaction factors of casino tourism. Fourth, economic, cultural and environmental impact of local communities. Thus, the main factors of casino tourism are affecting the casino's customer service and vitalization of the local economy. 


\subsection{Advance research}

Advance research on the experience of visiting casinos was conducted with previous studies of empirical, recreational and aesthetic factors. In that research, preferences, accessibility, recommendations of friends or relatives, past experiences, convenience of time, ease of leisure, advertising, quality of service and novelty were studied as factors of casino selection in abroad (Turco \& Riley, 1996). In addition, comprehensive casino appearance and atmosphere, employee kindness, food and beverage, provision of promised services, events and accessibility were studied as another factors (Kennedy, 2000).

Schmitt(1999) had defined a five-step systematic classification of casino experience; sensations, emotions, perceptions, behaviors and relationships. which means that the consumer was perceived as an emotional being in a new point of view, away from a view of consumer as simply rational being as features and benefits of a product or service (Park et al., 2007). Sternberg(2013) said tourism is selling planned experiences and tourism products are creating experiences.

In an advance research in Korea, casino facilities, dealer quality, stability and service of employees were used as essential elements of study. Furthermore, casino services, casino awareness, employee kindness, clean atmosphere and convenience of access were studied based on experiences of tourist in China and professionals (Seo et al., 2009). Also, the motivation of casino visit varies significantly depending on the casino select factors were founded $(\mathrm{Ku} \&$ Go, 2010) and a study on casino tourist satisfaction and loyalty according to casino selection factors were studied (Youn, 2012).

Casino selection factors were studied by separating the casino's hardware and software (Youn \& Kim, 2015) and an important factor in the development of the casino complex resort was studied through AHP technique on the casino options for game facilities, casino services and marketing, theme facilities, hotels and convention facilities, responsible management (Lee \& Kim, 2015). Also, the impact of casino tour motivation on casino selectivity and the difference between casino selectivity were studied by using IPA technique (Song \& Choi, 2018). A necessity of promotional and marketing strategies was studied based on a difference between the considerations and expectations of casino tourists (Song \& Kim, 2016). Therefore, the tourism experience is closely related to interconnectivity of the surrounding environment. As a result, the casino tourism experience can be summarized as one of the tourism activities, showing positive results and psychological state by physical and voluntary activities in the field (Han, 2005).

\section{Methodology}

\subsection{Research Model}

This study was designed with tourists of four casino resorts; Sands Cotai Central, C.O.D (City of Dream), Galaxy Macau and Venetian Macau, located in Taipa, Macau, which establish the world's largest complex casino resort system. Also, the research model was designed to study the effects on revisiting factors of casino tourism based on cultural motivation, experiential motivation, and psychological motivation.
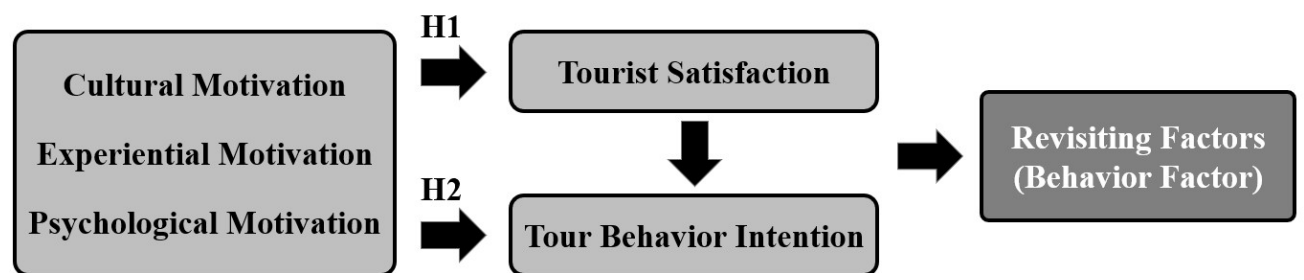

Figure 1: Casino tour research model

\subsection{Research Hypothesis}

\subsubsection{Research Hypothesis Setting}

The motivation of casino tour affects tourist satisfaction (Park \& Song, 2018) and it is correlation with satisfaction (Lee, 2004). The study was conducted on the relationship between casino tourist satisfaction and loyalty 
based on casino selection factors (Youn, 2012). Therefore, a research hypothesis based on the research model of this study established three sub-hypothesizes that motivation of casino tour affects tourist satisfaction.

H1 : Motivation of casino tour will have a significant impact on tourist satisfaction.

H1-1 : Cultural motivation will have a significant impact on tourist satisfaction.

H1-2 : Experiential motivation will have a significant impact on tourist satisfaction.

H1-3 : Psychological motivation will have a significant impact on tourist satisfaction.

The motivation of casino tour affects the satisfaction and revisit rate of casino tourists (Seo et al., 2009). Also, the motivation of casino tour varies significantly depending on the casino selection factors were founded $(\mathrm{Ku} \& \mathrm{Kim}$, 2010). Therefore, a research hypothesis based on the research model of this study established three sub-hypothesizes that motivation of casino tour affects behavior intention.

H2 : Motivation of casino tour will have a significant impact on behavior intention.

H2-1 : Cultural motivation will have a significant impact on behavior intention.

H2-2 : Experiential motivation will have a significant impact on behavior intention.

H2-3 : Psychological motivation will have a significant impact on behavior intention.

It has been demonstrated that high level of tourist satisfaction not only affects the behavior intention but also has a positive perception of products produced in the country of residence (De Nisco et al., 2015). In addition, tourist satisfaction has a significant impact on revisit and recommendation intentions, and it proved that tourists who are satisfied with their destination are more likely to recommend it to their surroundings than revisit it (Hui, T. K. et al., 2007). Therefore, a research hypothesis based on the research model of this study established that tourist satisfaction affects behavior intention.

H3 : Tourist satisfaction of casino will have a significant impact on behavior intention.

\subsubsection{Composition and design of questionnaire item}

The questionnaire was designed by modifying and supplementing existing researches to suit the purpose of this study. It was surveyed for tourists who experienced casino, and the survey site was limited to Macau, so it was written in Korean, Chinese and English. Questionnaire items were designed with 27 questions in seven areas, including cultural motivation, experiential motivation, psychological motivation, and measurements were made using Likert scale, nominal scale, ratio scale.

Table 1: Formation of questionnaire

\begin{tabular}{|c|c|c|c|c|}
\hline Classification & $\begin{array}{c}\text { Configuration } \\
\text { Dimension }\end{array}$ & Measurement Variable & Scale & $\begin{array}{c}\text { Number of } \\
\text { items }\end{array}$ \\
\hline \multirow{3}{*}{$\begin{array}{l}\text { Cultural } \\
\text { Motivation }\end{array}$} & $\begin{array}{l}\text { Commercial } \\
\text { Value }\end{array}$ & $\begin{array}{c}\text { Utilization of tour, products in Macau } \\
\text { casino }\end{array}$ & \multirow{3}{*}{$\begin{array}{c}\text { Likert } \\
5 \text { points Scale }\end{array}$} & \multirow{3}{*}{$\begin{array}{c}3 \\
\text { Items }\end{array}$} \\
\hline & $\begin{array}{l}\text { Local Culture } \\
\text { Connectivity }\end{array}$ & Connectivity with Macau local culture & & \\
\hline & $\begin{array}{l}\text { Expectation of } \\
\text { Casino }\end{array}$ & Expectation of Macau casino & & \\
\hline \multirow{3}{*}{$\begin{array}{l}\text { Experiential } \\
\text { Motivation }\end{array}$} & Interest & Interest of winning bet & \multirow{3}{*}{$\begin{array}{c}\text { Likert } \\
5 \text { points Scale }\end{array}$} & \multirow{3}{*}{$\begin{array}{c}3 \\
\text { Items }\end{array}$} \\
\hline & Pleasure & Pleasure and excitement & & \\
\hline & $\begin{array}{l}\text { Diversity of } \\
\text { Stories }\end{array}$ & Provided diversity of stories & & \\
\hline \multirow{2}{*}{$\begin{array}{l}\text { Psychological } \\
\text { Motivation }\end{array}$} & Curiosity & Curiosity of casino & \multirow{2}{*}{$\begin{array}{c}\text { Likert } \\
5 \text { points Scale }\end{array}$} & \multirow{2}{*}{$\begin{array}{c}3 \\
\text { Items }\end{array}$} \\
\hline & Memory & Memories and romantic experiences & & \\
\hline
\end{tabular}




\begin{tabular}{|c|c|c|c|c|}
\hline & Experimental & Unforgettable experience & & \\
\hline \multirow{3}{*}{ Satisfaction } & Diversity & Satisfaction of diversity of casino games & \multirow{3}{*}{$\begin{array}{c}\text { Likert } \\
5 \text { points Scale }\end{array}$} & \multirow{3}{*}{$\begin{array}{c}3 \\
\text { Items }\end{array}$} \\
\hline & Kindness & Satisfaction of kindness of casino staff & & \\
\hline & Winning Rate & $\begin{array}{c}\text { Satisfaction of high winning rate than } \\
\text { other regions }\end{array}$ & & \\
\hline \multirow{3}{*}{$\begin{array}{l}\text { Behavior } \\
\text { Intention }\end{array}$} & Revisitation & Intention of revisitation & \multirow{3}{*}{$\begin{array}{c}\text { Likert } \\
5 \text { points Scale }\end{array}$} & \multirow{3}{*}{$\begin{array}{c}3 \\
\text { Items }\end{array}$} \\
\hline & Vitalization & Vitalization of tour product & & \\
\hline & Introspection & Introspection on casino game & & \\
\hline $\begin{array}{l}\text { Population } \\
\text { Statics }\end{array}$ & - & $\begin{array}{c}\text { Gender, age, level of education, } \\
\text { occupation, monthly income, marriage }\end{array}$ & $\begin{array}{l}\text { Nominal Scale } \\
\text { Ratio Scale }\end{array}$ & $\begin{array}{c}6 \\
\text { Items }\end{array}$ \\
\hline Involved Type & - & $\begin{array}{c}\text { Visitation frequency of casino and } \\
\text { Macau, stay duration of Macau, } \\
\text { visitation frequency of casino during } \\
\text { stay in Macau, participation hour, types } \\
\text { of game }\end{array}$ & & $\begin{array}{c}6 \\
\text { Items }\end{array}$ \\
\hline \multicolumn{4}{|c|}{ Total items } & $\begin{array}{c}27 \\
\text { Items }\end{array}$ \\
\hline
\end{tabular}

\subsection{Condition analysis}

\subsubsection{Data Review}

The survey questionnaires were written in Korean, Chinese and English. The empirical research was conducted with on-site surveys and interviews of Macau casino visitors from August 8 to 13, 2019. A total of 220 copies were distributed and 193 copies were collected, but 13 copies were not conceded due to insincere responses, and a total of 180 cases were analyzed and utilized by the package program SPSS 21.0 .

Table 2: Characteristics of population statistic of respondents

\begin{tabular}{|c|c|c|c|c|c|c|c|}
\hline \multicolumn{2}{|c|}{ Classification } & \multirow{2}{*}{$\begin{array}{c}\text { Frequency } \\
105\end{array}$} & \multirow{2}{*}{$\begin{array}{c}\begin{array}{c}\text { Ratio } \\
(\%)\end{array} \\
58.3\end{array}$} & \multicolumn{2}{|c|}{ Classification } & \multirow{2}{*}{$\begin{array}{c}\text { Frequency } \\
39\end{array}$} & \multirow{2}{*}{$\begin{array}{r}\begin{array}{r}\text { Ratio } \\
(\%)\end{array} \\
21.7\end{array}$} \\
\hline \multirow{3}{*}{ Gender } & Male & & & \multirow{6}{*}{$\begin{array}{l}\text { Monthly } \\
\text { Income }\end{array}$} & $\begin{array}{c}\text { Below } 200 \\
\text { US\$ }\end{array}$ & & \\
\hline & Female & 75 & 41.7 & & $\begin{array}{c}200 \sim 300 \\
\text { US\$ }\end{array}$ & 54 & 30.0 \\
\hline & Total & 180 & 100.0 & & $\begin{array}{c}300 \sim 400 \\
\text { US\$ }\end{array}$ & 42 & 23.3 \\
\hline \multirow{7}{*}{ Age } & Under 20’s & 0 & 0.0 & & $\begin{array}{c}400 \sim 500 \\
\text { US\$ }\end{array}$ & 24 & 13.3 \\
\hline & 20 's & 26 & 14.4 & & $\begin{array}{c}\text { Above } 500 \\
\text { US\$ }\end{array}$ & 21 & 11.7 \\
\hline & 30 's & 41 & 22.7 & & Total & 180 & 100.0 \\
\hline & 40 's & 72 & 40.0 & \multirow{6}{*}{$\begin{array}{l}\text { Visitation } \\
\text { Frequency of } \\
\text { Casino } \\
\text { (Yearly) }\end{array}$} & Below 1 & 54 & 30.0 \\
\hline & 50 's & 30 & 16.7 & & $2 \sim 4$ & 73 & 40.6 \\
\hline & 60 's & 11 & 6.2 & & $5 \sim 8$ & 42 & 23.3 \\
\hline & Total & 180 & 100.0 & & Above 9 & 11 & 6.1 \\
\hline \multirow{2}{*}{ Occupation } & Student & 24 & 13.3 & & \multirow{2}{*}{ Total } & \multirow{2}{*}{180} & \multirow{2}{*}{100.0} \\
\hline & Agriculture, & 15 & 8.3 & & & & \\
\hline
\end{tabular}




\begin{tabular}{|c|c|c|c|c|c|c|c|}
\hline & $\begin{array}{l}\text { Forestry, and } \\
\text { Fishing }\end{array}$ & & & & & & \\
\hline & Private Business & 78 & 43.4 & \multirow{6}{*}{$\begin{array}{c}\text { Stay } \\
\text { Duration }\end{array}$} & 1 day & 76 & 42.2 \\
\hline & Business & 31 & 17.2 & & $2 \sim 3$ days & 45 & 25.0 \\
\hline & $\begin{array}{c}\text { Government } \\
\text { employ }\end{array}$ & 0 & 0.0 & & $3 \sim 4$ days & 38 & 21.1 \\
\hline & Homemaker & 32 & 17.8 & & $\begin{array}{c}\text { Above } 4 \\
\text { days }\end{array}$ & 21 & 11.7 \\
\hline & Others & 0 & 0.0 & & \multirow{2}{*}{ Total } & \multirow{2}{*}{180} & \multirow{2}{*}{100.0} \\
\hline & Total & 180 & 100.0 & & & & \\
\hline \multirow{6}{*}{$\begin{array}{l}\text { Level of } \\
\text { Education }\end{array}$} & $\begin{array}{c}\text { Elementary } \\
\text { school }\end{array}$ & 0 & 0.0 & \multirow{6}{*}{$\begin{array}{l}\text { Preference } \\
\text { Game }\end{array}$} & Baccarat & 43 & 23.9 \\
\hline & Middle school & 0 & 0.0 & & Blackjack & 16 & 8.9 \\
\hline & High school & 24 & 13.3 & & Roulette & 15 & 8.3 \\
\hline & Undergraduate & 122 & 67.8 & & $\begin{array}{c}\text { Slot } \\
\text { machine }\end{array}$ & 101 & 56.1 \\
\hline & $\begin{array}{c}\text { Above } \\
\text { undergraduate }\end{array}$ & 34 & 18.9 & & Others & 5 & 2.8 \\
\hline & Total & 180 & 100.0 & & Total & 180 & 100.0 \\
\hline
\end{tabular}

\subsubsection{Verification of sample reliability}

The reliability of the theoretical variables including casino tour experiences, satisfactions and intentions was found to be 0.792 of the Cronbach's $\alpha$ value. Accordingly, when the Cronbach's $\alpha$ value is greater than 0.6 , the reliability rate of the survey is generally considered as relatively reliable. The verification result of the Cronbach's $\alpha$ reliability for each items of questionnaire in this study shows all item factors have more than 0.6 so the validity of reliability is conceded.

Table 3: Analysis of reliability coefficient

\begin{tabular}{|c|c|c|}
\hline$\cdot$ & Number of Items & Cronbach's $\boldsymbol{\alpha}$ \\
\hline Reliability Coefficient & 27 & 0.797 \\
\hline
\end{tabular}

Table 4: Reliability test result of questionnaire

\begin{tabular}{|c|c|c|c|}
\hline Classification & Items & $\begin{array}{c}\text { Cronbach's } \\
\alpha\end{array}$ & Reliability $\alpha$ \\
\hline \multirow{6}{*}{$\begin{array}{l}\text { General condition of } \\
\text { Respondent }\end{array}$} & Gender & 0.821 & \multirow{10}{*}{0.797} \\
\hline & Age & 0.817 & \\
\hline & Level of Education & 0.803 & \\
\hline & Occupation & 0.814 & \\
\hline & Monthly Income & 0.816 & \\
\hline & Marriage & 0.815 & \\
\hline \multirow{4}{*}{$\begin{array}{l}\text { General condition of } \\
\text { Casino Tour }\end{array}$} & Visitation Frequency of Casino & 0.792 & \\
\hline & Visitation Frequency of Macau & 0.803 & \\
\hline & Stay Duration in Macau & 0.799 & \\
\hline & Visitation Frequency of Casino during stay in Macau & 0.746 & \\
\hline
\end{tabular}


Youngsoo CHOI, ChanSoon KIM / East Asian Journal of Business Economics 8(2), pp.43-56.

\begin{tabular}{|c|l|c|}
\hline \multirow{4}{*}{ Cultural Motivation } & Participation hour & 0.758 \\
\cline { 2 - 3 } & Types of game & 0.798 \\
\hline \multirow{4}{*}{ Experiential Motivation } & Utilization of Tour Products in Macau Casino & 0.811 \\
\cline { 2 - 3 } & Connectivity with Macau local culture & 0.805 \\
\cline { 2 - 3 } & Expectation of Macau Casino & 0.804 \\
\hline \multirow{3}{*}{$\begin{array}{c}\text { Psychological } \\
\text { Motivation }\end{array}$} & Interest of winning bet & 0.801 \\
\cline { 2 - 3 } & Pleasure and excitement & 0.808 \\
\cline { 2 - 3 } & Provided diversity of stories & 0.802 \\
\hline \multirow{3}{*}{ Satisfaction } & Curiosity of casino & 0.805 \\
\cline { 2 - 3 } & Memories and romantic experiences & 0.785 \\
\cline { 2 - 3 } & Unforgettable experience & 0.781 \\
\hline \multirow{3}{*}{ Behavior Intention } & Satisfaction of diversity of casino games & 0.798 \\
\cline { 2 - 3 } & Satisfaction of kindness of casino staff & 0.806 \\
\cline { 2 - 3 } & Satisfaction of high winning rate than other regions & 0.774 \\
\hline & Intention of revisitation & 0.805 \\
\cline { 2 - 3 } & Vitalization of tour product & 0.806 \\
\cline { 2 - 3 } & Introspection on casino game & 0.765 \\
\hline
\end{tabular}

\subsubsection{Verification of reliability and feasibility of casino tour experiences}

The results with exploratory factor analysis related to casino tour experiences were evaluated by 3 different variables of Kaiser-Meyer-Olkin (KMO) value in which had correlations with factor variables. The variance explanation power was rated as $73.334 \%$ and the KMO value that verified the feasibility of the survey used in this study was 0.900 , representing a satisfactory level of feasibility. Also, the Bartlett's test shows the statistical correlation of the factor variables at a significant level $(p<0.000)$, representing feasibility on conducting factor analysis. The reliability analysis of the independent variable of casino tour experience factors in which were applied with the above criteria, showed both feasibility and reliability.

Table 5: Exploratory factor analysis of casino tour experience (Independent variable)

\begin{tabular}{|c|c|c|c|c|c|c|}
\hline \multirow{2}{*}{ Type } & \multirow{2}{*}{ Classification } & \multicolumn{3}{|c|}{ Factor Loading Value } & \multirow{2}{*}{\multicolumn{2}{|c|}{ Cronbach's $\alpha$}} \\
\hline & & 1 & 2 & 3 & & \\
\hline \multirow{3}{*}{$\begin{array}{l}\text { Cultural } \\
\text { Motivation }\end{array}$} & $\begin{array}{l}\text { Utilization of Tour Products in } \\
\text { Macau Casino }\end{array}$ & 0.788 & & & 0.811 & \multirow{3}{*}{0.806} \\
\hline & $\begin{array}{l}\text { Connectivity with Macau local } \\
\text { culture }\end{array}$ & 0.836 & & & 0.805 & \\
\hline & Expectation of Macau Casino & 0.701 & & & 0.804 & \\
\hline \multirow{3}{*}{$\begin{array}{l}\text { Experiential } \\
\text { Motivation }\end{array}$} & Interest of winning bet & & 0.622 & & 0.801 & \multirow{3}{*}{0.803} \\
\hline & Pleasure and excitement & & 0.833 & & 0.808 & \\
\hline & Provided diversity of stories & & 0.747 & & 0.802 & \\
\hline \multirow{3}{*}{$\begin{array}{l}\text { Psychological } \\
\text { Motivation }\end{array}$} & Curiosity of casino & & & 0.829 & 0.805 & \multirow{3}{*}{0.790} \\
\hline & Memories and romantic experiences & & & 0.688 & 0.785 & \\
\hline & Unforgettable experience & & & 0.618 & 0.781 & \\
\hline & Eigen-value & 5.971 & 1.213 & 0.835 & \multicolumn{2}{|c|}{$\begin{array}{c}\text { Total variance } \\
\text { explanation powe }\end{array}$} \\
\hline
\end{tabular}


Youngsoo CHOI, ChanSoon KIM / East Asian Journal of Business Economics 8(2), pp.43-56.

\begin{tabular}{|l|l|l|l|l|}
\hline Variance extracted (\%) & 49.767 & 10.116 & 6.966 & \multirow{2}{*}{$73.334 \%$} \\
\cline { 1 - 3 } Rotary dispersion (\%) & 19.172 & 19.045 & 18.818 & \\
\hline
\end{tabular}

Table 6: Validity and reliability analysis of casino tour experience

\begin{tabular}{|c|l|c|c|c|c|}
\hline \multirow{2}{*}{ Type } & \multicolumn{1}{|c|}{ Classification } & Average & $\begin{array}{c}\text { Standard } \\
\text { Deviation }\end{array}$ & $\begin{array}{c}\text { Factor } \\
\text { Loading }\end{array}$ & $\begin{array}{c}\text { Common } \\
\text { Value }\end{array}$ \\
\hline \multirow{3}{*}{$\begin{array}{c}\text { Cultural } \\
\text { Motivation }\end{array}$} & $\begin{array}{l}\text { Utilization of Tour Products in } \\
\text { Macau Casino }\end{array}$ & 3.85 & .820 & .788 & .689 \\
\cline { 2 - 6 } & $\begin{array}{l}\text { Connectivity with Macau local } \\
\text { culture }\end{array}$ & 4.17 & .697 & .836 & .791 \\
\cline { 2 - 6 } & Expectation of Macau Casino & 4.30 & .687 & .701 & .696 \\
\hline \multirow{3}{*}{$\begin{array}{c}\text { Experiential } \\
\text { Motivation }\end{array}$} & Interest of winning bet & 3.99 & .797 & .622 & .620 \\
\cline { 2 - 6 } & Pleasure and excitement & 3.81 & .759 & .833 & .810 \\
\cline { 2 - 6 } & Provided diversity of stories & 3.83 & .74 .4 & .746 & .766 \\
\hline \multirow{3}{*}{$\begin{array}{c}\text { Psychological } \\
\text { Motivation }\end{array}$} & Curiosity of casino & 3.95 & .777 & .829 & .840 \\
\cline { 2 - 6 } & $\begin{array}{l}\text { Memories and romantic } \\
\text { experiences }\end{array}$ & 4.27 & .757 & .688 & .798 \\
\cline { 2 - 6 } & Unforgettable experience Kiser Myer Okin value =0.900 & .783 & .618 & .672 \\
\hline & \multicolumn{2}{|l}{4.21} & & \\
\hline
\end{tabular}

\subsubsection{Verification of reliability and feasibility of casino tourist satisfaction}

A total of 1 factor was verified with the factor analysis of casino tourist satisfaction, and the total variance explanation power of the verified factor was $74.214 \%$. To verify the suitability of the verified factor analysis, Bartlett's test and the KMO value were evaluated. The Bartlett's test, showed significant probability of 0.000 proving the feasibility of verified factor analysis, and also the KMO measure of the verified factor analysis resulted 0.722 representing a positivity. The commonality of the total variance explanation power of each individual survey questions to the overall factors were favorable, representing different rates between 0.721 to 0.790 . And the factor loading values associated with the factor configuration variables were rated in-between 0.807-0.866, indicating that the measuring factors were suitable for the current study.

Since the variance explanation power of the extracted factor variables showed $74.214 \%$ of casino tourist satisfaction, the same factor was named as casino tourist satisfaction due to conceptual relevance. The reliability for casino tourist satisfaction was tested with Cronbach's $\alpha$ and showed a relatively high reliability and internal consistency rating 0.830 . Therefore, the measurement tools used in this study for casino tourist satisfaction was regarded as valid and reliable.

Table 7: Exploratory factor analysis of casino tour experience (dependent variable)

\begin{tabular}{|c|l|c|c|c|c|}
\hline \multirow{2}{*}{ Type } & \multicolumn{1}{|c|}{ Classification } & $\begin{array}{c}\text { factor loading } \\
\text { Value }\end{array}$ & Communality & \multicolumn{2}{|c|}{$\begin{array}{c}\text { Cronbach's } \\
\boldsymbol{\alpha}\end{array}$} \\
\hline \multirow{2}{*}{$\begin{array}{l}\text { Satisfaction of } \\
\text { Casino tourist }\end{array}$} & $\begin{array}{l}\text { Satisfaction of diversity of } \\
\text { casino games }\end{array}$ & .807 & .721 & .695 & \multirow{2}{*}{.830} \\
\cline { 2 - 5 } & $\begin{array}{l}\text { Satisfaction of kindness of } \\
\text { casino staff }\end{array}$ & .866 & .790 & .789 & .867 \\
\cline { 2 - 5 } & $\begin{array}{l}\text { Satisfaction of high winning } \\
\text { rate than other regions }\end{array}$ & .827 & .746 & .807 \\
\hline
\end{tabular}




\begin{tabular}{|l|c|c|}
\hline Eigen-value & 2.251 & $\begin{array}{c}\text { Total variance } \\
\text { explanation power }\end{array}$ \\
\hline Variance extracted (\%) & 75.040 & $74.214 \%$ \\
\hline \multicolumn{2}{|c|}{ KMO $: .772$, Bartlett test : 335.142 (p-value:0.000), df $=3$} \\
\hline
\end{tabular}

\subsubsection{Verification of reliability and validity of intentional behaviors showed in casino tour}

The result analyzed with the factors of intentional behavior's at casino tour showed $93.11 \%$ of variance explanation power within the total variable. And according to the Bartlett's test, the Bartlett's significance rate was 0.000 , showing suitability for factor analysis, and KMO's sample compatibility test measures were found to be relatively high with 0.784 points.

The commonality of the variance explanation power for the overall factors of individual survey questions were rated quite high showing results in-between 0.930 to 931 , and the factor loading value related to the factor composition variables were rated in-between 0.925 to 0.931 , indicating high suitability in the measured factors. Since, the variance explanation power of the extracted factor variables showed $89.102 \%$ of casino tourist satisfaction, the same factor was named as casino tourist satisfaction due to conceptual relevance. The reliability of casino tourist satisfaction was verified with Cronbach's $\alpha$, and showed relatively high reliability and internal consistency rating 0.641 . However, in casino reflection, Cronbach's $\alpha$ was found to be 0.641 , representing a value below the confidence level.

Therefore, the measurement tools used in this study for casino tourist satisfaction was confirmed with validity and reliability.

Table 8: Exploratory factor analysis of behavior intention (dependent variable)

\begin{tabular}{|c|c|c|c|c|c|}
\hline Type & Classification & $\begin{array}{c}\text { factor loading } \\
\text { Value }\end{array}$ & Communality & \multicolumn{2}{|c|}{$\begin{array}{c}\text { Cronbach's } \\
\alpha\end{array}$} \\
\hline \multirow{3}{*}{$\begin{array}{l}\text { Behavior } \\
\text { Intention }\end{array}$} & Intention of revisitation & .925 & .931 & .983 & \multirow{2}{*}{.925} \\
\hline & Vitalization of tour product & .931 & .930 & .933 & \\
\hline & Introspection on casino game & .645 & .639 & .641 & .641 \\
\hline \multicolumn{2}{|l|}{ Eigen-value } & \multicolumn{2}{|c|}{1.857} & \multicolumn{2}{|c|}{$\begin{array}{c}\text { Total variance } \\
\text { explanation power }\end{array}$} \\
\hline \multicolumn{2}{|c|}{ Variance extracted (\%) } & \multicolumn{2}{|c|}{93.031} & \multicolumn{2}{|c|}{$89.102 \%$} \\
\hline \multicolumn{6}{|c|}{ KMO $: .784$, Bartlett test $: 392.557(p-$ value: 0.000$), \mathrm{df}=1$} \\
\hline
\end{tabular}

\subsection{Test of hypothesis}

\subsubsection{Verification and analysis between casino tour motivation and satisfaction}

H1 : Motivation of casino tour will have a significant impact on tourist satisfaction.

H1-1 : Cultural motivation will have a significant impact on tourist satisfaction.

H1-2 : Experiential motivation will have a significant impact on tourist satisfaction.

H1-3 : psychological motivation will have a significant impact on satisfaction.

Multiple regression analysis was accomplished to verify the research theory $\mathrm{H} 1$ 'the motivation of casino tour (cultural motivation, experiential motivation, and psychological motivation) will have a significant impact on tourist satisfaction' as follows. 
Table 9: Effect on the motivation of casino tours on tourist satisfaction

\begin{tabular}{|c|c|c|c|c|c|c|c|c|}
\hline \multirow{2}{*}{$\begin{array}{c}\text { Dependent } \\
\text { Variable }\end{array}$} & \multirow{2}{*}{$\begin{array}{l}\text { Independent } \\
\text { Variable }\end{array}$} & \multicolumn{2}{|c|}{$\begin{array}{c}\text { Non- } \\
\text { standardized } \\
\text { coefficient }\end{array}$} & \multirow{2}{*}{$\begin{array}{c}\text { Standardized } \\
\text { coefficient } \\
\text { Beta }\end{array}$} & \multirow{2}{*}{$\begin{array}{c}\mathbf{t} \\
\text { value }\end{array}$} & \multirow{2}{*}{$\begin{array}{c}\quad p \\
\text { (significance } \\
\text { probability) }\end{array}$} & \multicolumn{2}{|c|}{$\begin{array}{l}\text { Collinearity } \\
\text { Statistics }\end{array}$} \\
\hline & & $\boldsymbol{\beta}$ & S.E & & & & $\begin{array}{l}\text { Toleran } \\
\text { ce limit }\end{array}$ & VIF \\
\hline \multirow{4}{*}{$\begin{array}{l}\text { Satisfaction } \\
\text { of tourist }\end{array}$} & (Constant) & .354 & .187 & - & 2.064 & 0.040 & - & - \\
\hline & Cultural & .106 & .054 & .094 & 2.076 & 0.021 & 0.605 & 1.156 \\
\hline & Experiential & .139 & .058 & .141 & 2.565 & 0.011 & 0.451 & 2.206 \\
\hline & Psychological & .152 & .057 & .152 & 2.887 & 0.003 & 0.465 & 2.2067 \\
\hline \multicolumn{9}{|c|}{$\mathrm{R}=0.805, \mathrm{R}^{2}=0.650$, adjusted $\mathrm{R}^{2}=0.643, \mathrm{~F}=126.145, \mathrm{p}=0.000$} \\
\hline
\end{tabular}

The regression analysis of research theory $\mathrm{H} 1$ showed that the $\mathrm{F}$ value is significant with 126.145 at $\mathrm{p}<0.001$ and the tolerance limit was greater than 0.10 and the VIF was less than 10 , proving the rationality of co-linearity. $\mathrm{R}^{2}$ was found as 0.650 from the regression explanation power of research theory H1 and it explains that the motivation of casino tours is 65.0 percent of the total tourist satisfaction spread. The independent variable, the motivation factor of casino tour, was $\mathrm{p}<0.001$, which was found to have a positive $(+)$ effect on satisfaction.

The results of the verification of casino tourist satisfaction significance, such as cultural, experiential, psychological, which were analyzed through multiple regression formula of independent variable for tourist satisfaction, shall be as follows: Firstly, the cultural nature of the casino tour motivation showed that $\mathrm{t}$ value was $2.076(\mathrm{p}=0.021<0.05)$ with a significant positive $(+)$ effect. Secondly, the experiential showed that $\mathrm{t}$ value was $2.565(\mathrm{p}=0.011<0.05)$ with a significant affecting positive $(+)$ effect. Thirdly, the psychological factor shows that $\mathrm{t}$ value was $2.887(\mathrm{p}=0.003<0.01)$ with a significant affecting positive $(+)$ effect. Therefore, all of research theory $\mathrm{H} 1$ were selected.

\subsubsection{Verification and analysis between casino visit motivation and behavior intention}

H2 : Motivation of casino tour will have a significant impact on behavior intention.

H2-1 : Cultural motivation will have a significant impact on behavior intention.

H2-2 : Experiential motivation will have a significant impact on behavior intention.

H2-3 : Psychological motivation will have a significant impact on behavior intention.

Multiple regression analysis was accomplished to verify the research theory $\mathrm{H} 2$ 'the motivation of casino tour (cultural motivation, experiential motivation, and psychological motivation) will have a significant impact on behavior intention'. The result showed that the model's explanatory power $\left(\mathrm{R}^{2}\right)$ was $54.2 \%$. The result for the overall model of the regression formula showed that the $\mathrm{F}$ value of the model was $80.486(\mathrm{p}=0.000)$, which was significant to the dependent variable (tourist satisfaction), and that model was suitable due to positive $(+)$ effect.

The motivation of casino tour has been verified by multiple regression formula to verify whether they significantly affect behavior intention. Validation of the significance of the lower independent factors are shown as follows: Firstly, the cultural nature of the behavior intention shows that $t$ value was $2.098(\mathrm{p}=0.004<0.05)$ with a significant positive $(+)$ effect. Secondly, the experiential shows that $t$ value was $2.429(\mathrm{p}=0.019<0.05)$ with a significant positive $(+)$ effect. Thirdly, the psychological factor shows $t$ value was $-0.158(\mathrm{p}=0.0875>0.05)$ with a significant negative (-) effect so the psychological factor does not significantly affect. Therefore, research theory H2 were partially selected.

Table 10: Effect of the motivation of casino tours on behavior intention

\begin{tabular}{|c|c|c|c|c|c|c|}
\hline $\begin{array}{c}\text { Dependent } \\
\text { Variable }\end{array}$ & $\begin{array}{c}\text { Independent } \\
\text { Variable }\end{array}$ & $\begin{array}{c}\text { Non- } \\
\text { standardized } \\
\text { coefficient }\end{array}$ & $\begin{array}{c}\text { Standardized } \\
\text { coefficient } \\
\text { Beta }\end{array}$ & $\begin{array}{c}\mathbf{t} \\
\text { value }\end{array}$ & $\begin{array}{c}\mathbf{p} \\
\text { (significance } \\
\text { probability) }\end{array}$ & $\begin{array}{c}\text { Collinearity } \\
\text { Statistics }\end{array}$ \\
\hline
\end{tabular}




\begin{tabular}{|c|c|c|c|c|c|c|c|c|}
\hline & & $\boldsymbol{\beta}$ & S.E & & & & $\begin{array}{c}\text { Tolerance } \\
\text { limit }\end{array}$ & VIF \\
\hline \multirow{3}{*}{$\begin{array}{c}\text { Behavior } \\
\text { Intention }\end{array}$} & (Constant) & .336 & .243 & - & 1.385 & .016 & & \\
\cline { 2 - 9 } & Cultural & .140 & .063 & .112 & 2.098 & .004 & .614 & 1.635 \\
\cline { 2 - 9 } & Experiential & .175 & .069 & .151 & 2.429 & .019 & .459 & 2.161 \\
\cline { 2 - 9 } & Psychological & -.012 & .069 & -.007 & -.158 & .875 & .465 & 2.129 \\
\hline \multicolumn{7}{|c|}{$\mathrm{R}=0.733, \mathrm{R}^{2}=0.544$, adjusted $\mathrm{R}^{2}=0.537, \mathrm{~F}=80.486, \mathrm{p}=0.000$} \\
\hline
\end{tabular}

$* \mathrm{p}<.05, * * \mathrm{p}<.01, * * * \mathrm{p}<.001$ shows significance statistics level

\subsubsection{Verification and analysis between casino tourist satisfaction and behavior intention}

H3 : Tourist satisfaction of casino will have a significant impact on behavior intention.

Simple regression analysis was accomplished to verify the research theory $\mathrm{H} 3$ 'the tourist satisfaction will have a significant impact on behavior intention'. The model's explanatory power $\left(\mathrm{R}^{2}\right)$ was $55.4 \%$. The result for the overall model of the regression formula showed that the $\mathrm{F}$ value of the model was 333.20, a significant probability of 0.000 $(\mathrm{p}<0.05)$ has been verified to be significant for the dependent variable (behavior intention). Validation result shows that the regression formula was suitable for this model. In addition, a comparison of the nominal coefficient to determine the degree of impact of tourist satisfaction factors on the revisit intention showed that tourist satisfaction rate was highly impact with value of 0.729 and the $t$ value of tourist satisfaction was also significantly impact with value of $18.521(\mathrm{p}=0.000<0.001)$.

Table 11: Effect of the casino tourist satisfaction on the behavior intention

\begin{tabular}{|c|c|c|c|c|c|c|c|c|}
\hline \multirow{2}{*}{$\begin{array}{c}\text { Dependent } \\
\text { Variable }\end{array}$} & \multirow{2}{*}{$\begin{array}{l}\text { Independent } \\
\text { Variable }\end{array}$} & \multicolumn{2}{|c|}{$\begin{array}{c}\text { Non- } \\
\text { standardize } \\
\text { d coefficient }\end{array}$} & \multirow{2}{*}{$\begin{array}{c}\text { Standardized } \\
\text { coefficient } \\
\text { Beta }\end{array}$} & \multirow{2}{*}{$\begin{array}{c}t \\
\text { value }\end{array}$} & \multirow{2}{*}{$\begin{array}{c}\mathbf{p} \\
\text { (significance } \\
\text { probability) }\end{array}$} & \multicolumn{2}{|c|}{$\begin{array}{l}\text { Collinearity } \\
\text { Statistics }\end{array}$} \\
\hline & & $\boldsymbol{\beta}$ & S.E & & & & $\begin{array}{c}\text { Tolerance } \\
\text { limit }\end{array}$ & VIF \\
\hline \multirow{2}{*}{$\begin{array}{l}\text { Behavior } \\
\text { intention }\end{array}$} & (Constant) & .715 & .187 & - & 3.817 & .000 & & \\
\hline & $\begin{array}{c}\text { Tourist } \\
\text { satisfaction }\end{array}$ & .841 & .042 & .729 & 18.521 & .000 & 1.000 & 1.000 \\
\hline & \multicolumn{8}{|c|}{$\mathrm{R}=0.738, \mathrm{R}^{2}=0.554$, adjusted $\mathrm{R}^{2}=0.565, \mathrm{~F}=333.20, \mathrm{p}=0.000$} \\
\hline
\end{tabular}

$* \mathrm{p}<.05, * * \mathrm{p}<.01, * * * \mathrm{p}<.001$ shows significance statistics level

\section{Results}

This study analyzed the impact of casino tour on visit motivation, tourist satisfaction and behavior intention with Macau tourists visiting casino resort. The results of the research on empirical analysis are as follows. Firstly, the exploratory factor analysis and reliability analysis of each variables were verified to confirm the validity and reliability of the survey samples. The factor loading value of factor extraction was adopted as a variable of 0.5 or higher, and the reliability was obtained at least 0.7 or higher. As a result of the factor analysis, three independent factors were derived: cultural factor, experiential factor, and psychological factor, and six sub-factors of casino game diversity, kindness, higher winning rate, revisit intention, activation and introspection were derived.

Secondly, the results of the hypothesis verification of the research model showed that there were partial differences between 12 sub-hypothesis of population statistics characteristics in terms of visit motivation, tourist satisfaction and behavior intention. The characteristic of casino tourists of visit motivation was found to affect both tourist satisfaction and behavior intention depending on the characteristics between factors. 
Youngsoo CHOI, ChanSoon KIM / East Asian Journal of Business Economics 8(2), pp.43-56.

Thirdly, the result of sub-factors route analysis shows that the visit motivation has the significant impact on each cultural factor and experiential factor. However, psychological factor did not have a significant positive (+) effect. The satisfaction shows the highly significant impact on sub-factors of casino game diversity, kindness and higher winning rate. Moreover, behavior intention has the highly significant impact on sub-factors of revisit, activation and introspection. Lastly, the verification of the research theory in this study has verified the suitability of the model path based on empirical analysis data. In the hypothesis H1, the regression analysis on the factors of the influence of casino tour motivation on tourism satisfaction showed that the $F$ value is significant with 126.145 at $p<0.001$ and the tolerance limit was greater than 0.10 and the VIF was less than 10 , proving the rationality of co-linearity. The result of model's explanatory power $\left(\mathrm{R}^{2}\right)$ on behavior intention was found as $65.0 \%$. The independent variable, the motivation factor of casino tour, showed $\mathrm{p}<0.001$, which was found to have a positive $(+)$ effect on satisfaction. Moreover, all of research theory H1 were adapted due to all $t$ values, cultural (2.076), experimental (2.565) and psychological (2.887), were significantly verified.

In the hypothesis $\mathrm{H} 2$, the regression analysis on the factors of the influence of casino tour motivation on behavior intention showed that the $\mathrm{F}$ value is significant with 80.486 at $\mathrm{p}<0.001$ and the tolerance limit was greater than 0.10 and the VIF was less than 10 , proving the rationality of co-linearity. The result of model's explanatory power $\left(\mathrm{R}^{2}\right)$ on behavior intention was found as $54.4 \%$. The factors on motivation of casino tour was $\mathrm{p}<0.001$ which was found to have a positive $(+)$ effect. Moreover, research theory $\mathrm{H} 2$ were partially adapted due to $t$ values were shown to verify significant influence in cultural (2.098) and experience (2.429), but psychological (-0.158) did not have significant influence.

In the hypothesis $\mathrm{H} 3$, the regression analysis on the factors of the influence of tourist satisfaction on behavior intention showed that the $F$ value is significant with 333.20 at $p<0.001$ and the tolerance limit was greater than 0.10 and the VIF was less than 10, proving the rationality of co-linearity.

The result of model's explanatory power $\left(\mathrm{R}^{2}\right)$ showed the influence of tourist satisfaction on behavior intention with value of $55.4 \%$. The factors on behavior intension was $\mathrm{p}<0.001$ which was found to have a positive $(+)$ effect. In addition, the t-value for tourist satisfaction was 0.729 and it verified to have a significant effect on the behavior intention of dependent variable.

\section{Conclusion}

\subsection{Conclusion of study}

The impact of casino visit motivation, tourist satisfaction and behavior intention on tourists was analyzed through academic and practical implications based on the empirical analysis of this study results.

Academic implications for empirical analysis are as follows. Firstly, the most important element of the casino tour experience in relation to the motivation and satisfaction is identified as the preceding concept of tourist satisfaction. In other words, the focus was on explaining the relationship between tour motivation \& casino tour and experiential \& tourist satisfaction. Therefore, the types of casino tour experiences were identified with concepts that were significantly influenced by tour motivation and significantly affected tourist satisfaction. Secondly, in order to improve the revisit ratio among the factors of behavior in the relationship between the visit motivation and behavior intention, the factors of visit motivation should be analyzed to strengthen cultural and empirical factors. Also, the weak significant impact of psychological factor should also be strengthened to influence all components of casino tour behavior intention. Lastly, in the relationship between motivation of casino visit and behavior intention, the visit satisfaction factors (revisit, visit opportunity and recommendation of others) are affecting the behavior intention with recognition factors such as curiosity, memory and unforgettable experience.

In addition, practical implications of this study results are analyzed as follows. Firstly, based on the research result that satisfaction of casino visitors are influenced by the experiential visit motivation with a significant positive $(+)$ effect, efforts should be made to enhance tourist satisfaction when developing casino tourist service programs and establishing casino marketing operation strategies. Secondly, cultural and experiential visit motivation and psychological motivation have a positive impact on mutual satisfaction, which shows that casino tourists want to get the adventure and experiential motivation and psychological stability through casino resort visit. Therefore, the marketing of casino tour is based on understanding tourists' needs and increasing satisfaction. Thirdly, satisfaction of casino tourist has been proven to have a positive effect on behavior intention. For the continued development of casino tourist, the priority is to improve the satisfaction of tourists visiting casinos. Therefore, in order to revitalize the casino tour industry, continuous research and development is required to accurately grasp the needs of casino tourists, including development of experience programs, along with the satisfaction of tourist. Fourthly, this study 
Youngsoo CHOI, ChanSoon KIM / East Asian Journal of Business Economics 8(2), pp.43-56.

shows unique value as an in-depth interaction analysis of the motivation, satisfaction and behavior of the casino tourist experience that could not be identified in the advance research.

\subsection{Limitation of study}

Although this study suggests the correlation between satisfaction and behavior according to the visitor's motivation to casino tour. However, the insufficient limitations of this study are presented as follows for review in subsequent studies. Firstly, the place marketing of this study is concerned due to the convenient sampling of this study was conducted a direct interview on tourists who have been to four casinos in Macau Taipa island. Therefore, comprehensive research is recommended with expanding the scope of subjects for subsequent studies. Secondly, the survey was conducted in Korean, Chinese, and English editions to analyzed the survey questions by language. However, the entire survey was analyzed comprehensively due to the time constraints of the sample survey. Further research verification is required for this point. Thirdly, advance research data such as visit motivation, tourist satisfaction, behavior intention of casino tourist were inadequate so the comparative review with advance research data was insufficient. Therefore, subsequent studies require comprehensive research that extends the area and scope of the research to secure the identity of factors that revitalize the casino tourism industry.

\section{Reference}

De Nisco, A., Mainolfi, G., Marino, V., \& Napolitano, M. R. (2015). Tourism satisfaction effect on general country image, destination image, and post-visit intentions, Journal of Vacation Marketing, 21(4), 305-317.

Han, S. Y. (2005). A Study on the Characteristics of Field Experience in the Heritage Site, Tourism Research, 20(2), 55-69.

Hui, T. K., Wan, D., \& Ho, A. (2007). Tourists' satisfaction, recommendation and revisiting Singapore. Tourism management, 28(4), 965-975.

Jeung, K. Y. (1999). Market analysis of Korean casino industry. Research tourism, 22(1), 245-255.

Kim, J. S. (2002). A study on the tourism strategy of sore-pogu using the concept of authenticity. Journal of Tourism Management Research, 6(2), 19-36.

$\mathrm{Ku}, \mathrm{H}$. J., \& Kim, Y. K. (2010). A study on the characteristics and customer satisfaction of visiting motives of foreign casino customers in Korea. Tourism Leisure Research, 22(4), 283-300.

Lee, C., \& Kyun, K., \& Kim, K. (2019), Understanding the casino industry : principles \& practice. Seoul, Korea: Daewang Publishing, 75-83.

Lee, C. K., \& Kim, N. H. (2015). Analysis of development strategy factors and priorities of the complex resort casino using AHP. Journal of Tourism Sciences, 39(2), 69-84.

Lee, H. C. (2004). The effect of the five-day workweek on tourism demand. Research in tourism, 28(1), 43-61.

Lee, S. L. (2007). The effect of casino service cape on customer satisfaction. Kyonggi, Korea: Doctorial dissertation, Kyonggi University

Park, J. H., \& Song, D. J. (2018). A study on the impact of satisfaction of casino selection attributes on revisit intention and moderating role of consumption experience. Journal of tourism management research, 22(3), 253282.

Park, S. k., Park, G. H., \& Cha, T. H. (2007). Effects of experience on enjoyment, satisfaction, and revisit intention: Pine and Gilmore's experience economy perspective. Journal of Consumer Research, 76(3), 55-78.

Schmitt. (1999). Experiential Marketing. Free Press.

Song, D. J., \& Choi, W. S. (2018). A study on the effect of casino motivation on casino selection attributes and the differences in casino selection attributes using an importance-performance analysis(IPA). Tourism Research, 43(1), 159-183.

Seo, W. S., Back, J. A., \& Son, M. L. (2009). A study on the marketing strategy of the casino industry for the increase of Chinese tourists. Tourism Leisure Research, 21(1), 107-123.

Song, S. Y., \& Kim, D. K. (2016). The impact of international tourists' visit experience on satisfaction and postbehavior. Journal of tourism \& leisure research, 23(1), 79-96.

Sternberg, R. J. (2013). Searching for love. The Psychologist, 26(2), 98-101. 
Turco, D. M., \& Riley, R. W. (1996). Choice factors and alternative activities for riverboat gamblers. Journal of Travel Research, 34(3), 24-29.

Won, G., \& Han, J., \& Lim, J. (2005). Casino Industry Theory. Seoul, Korea: Gimun Publishing.

Yang, B. S. (2006). Relations of tourist experience, authenticity, and tourist satisfaction towards cultural tourism sites. Busan, Korea: Doctorial dissertation, Dong A University.

Yang, H. S. (2014). The Effect of the internal marketing of Casino on the business Performance: subject on Customer Orientation. Journal of convention sciences, 37(1), 283-304.

Yoo, S. H., \& Kim, K. S. (2015). The relationship between the game motivation choice attributes and the intention to revisit overseas casino customers. Tourism Leisure Research, 27(1), 119-138.

Yun, M. K. (2012). A study on the satisfaction and loyalty of casino by casino choice attributes: focusing on the participants of foreign conference in Korea. Seoul, Korea: Doctorial dissertation, Kyung Hee University.

Yun, Y. S., \& Lee, J. J. (2004). An analysis of customers' casino choice linkage factor. Journal of Tourism Research, $18(1), 81-90$. 